\title{
Pengaruh Jumlah Wajib Pajak dan Jumlah Surat Pemberitahuan terhadap Penerimaan Pajak Penghasilan (Studi Empiris pada KPP Pratama Bukittinggi Periode 2014-2016)
}

\author{
Sri Amanah ${ }^{1}$, Popi Fauziati ${ }^{2}$, Daniati Puttri ${ }^{3}$ \\ ${ }^{1,2,3}$ Universitas Bung Hatta, Padang, Indonesia \\ popifauziati@bunghatta.ac.id
}

\begin{abstract}
This study determines the effect number of taxpayer and number of notification letter to income tax revenue. The type of data used are secondary data. Sources of the data used in this research is come from of Bukittinggi tax office. This research used data from January 2014 to December 2016. The data analysis technique used for this research is multiple linear regression, with dependent variable is income tax revenue and independent variable is number of taxpayer and number of notification letter. The result of study reveal that, simultaneously prove that number of taxpayer and number of notification letter have a effect to income tax revenue, partially prove that number of taxpayer have a effect to income tax revenue but number of notification letter has no effect to income tax revenue.
\end{abstract}

Keywords : tax, income tax revenue, number of taxpayer, number of notification letter.

\begin{abstract}
Abstrak
Penelitian ini bertujuan untuk mengetahui pengaruh jumlah wajib pajak dan jumlah surat pemberitahuan terhadap penerimaan pajak penghasilan. Jenis data yang digunakan adalah data sekunder. Sumber data dalam penelitian ini yaitu data yang berasal dari Kantor Pelayanan Pajak Pratama Kota Bukittinggi. Penelitian ini menggunakan data bulanan mulai Januari 2014 sampai Desember 2016 sebanyak 36 bulan. Teknik analisis data yang digunakan adalah analisis regresi lenear berganda, dengan variabel dependen penerimaan pajak penghasilan, dan variabel independen adalah jumlah wajib pajak dan jumlah surat pemberitahuan. Hasil penelitian menunjukkan bahwa, secara simultan membuktikan bahwa jumlah wajib pajak dan jumlah surat pemberitahuan berpengaruh terhadap penerimaan pajak penghasilan, secara parsial menunjukkan bahwa jumlah wajib pajak berpengaruh terhadap penerimaan pajak penghasilan, sedangkan jumlah surat pemberitahuan tidak berpengaruh terhadap penerimaan pajak penghasilan.
\end{abstract}

Kata kunci : pajak, penerimaan pajak penghasilan, wajib pajak, surat pemberitahuan.

\section{Pendahuluan}

Indonesia sebagai negara yang sedang berkembang, perlu menyusun dan menyelenggarakan pembangunan untuk kesejahteraan rakyatnya baik berupa pembangunan fisik maupun non fisik. Pemerintah Indonesia memerlukan biaya yang tidak sedikit dalam rangka menyelenggarakan dan menjalankan pembangunan, maupun kegiatan negara 
dan pemerintahan, untuk itu butuh dana yang besar untuk mewujudkannya. Pembiayaan pembangunan, kegiatan negara dan pemerintahan ini direalisasikan dalam Anggaran Pendapatan dan Belanja Negara (APBN). Sumber dana APBN berasal dari berbagai sumber, salah satu penyumbang sumber dana terbesar APBN berasal dari pajak (Friskianti dan Bestari, 2014).

Menurut UU No. 28 Pasal 1 Tahun 2007 dalam Resmi (2014) pajak adalah kontribusi wajib kepada negara yang terutang oleh orang pribadi atau badan yang bersifat memaksa berdasarkan Undang-Undang, dengan tidak mendapatkan imbalan secara langsung dan digunakan untuk keperluan negara bagi sebesar-besarnya kemakmuran rakyat.

Melalui pajak, pemerintah dapat mengoptimalkan penerimaan negara untuk pembangunan dalam negeri. Semakin besar penerimaan pajak, maka semakin besar pula kemampuan negara untuk membiayai pembangunan. Sebaliknya, semakin kecil penerimaan pajak, maka semakin kecil kemampuan negara untuk membiayai pembangunan. Setiap tahun pemerintah selalu berusaha agar penerimaan negara selalu meningkat. Penerimaan pajak diharapkan dapat meningkat dengan cara mengoptimalkan jumlah wajib pajak dan jumlah Surat Pemberitahuan (SPT).
Setiap transaksi pembayaran yang umumnya terjadi, yang dilakukan dengan uang selalu ada tanda bukti penerimaannya. Misalnya kwitansi pembayaran, struk pembayaran, nota pembayaran, dan lainnya. Namun, untuk pembayaran dan pelaporan hal-hal yang berkaitan dengan kewajiban perpajakan, mulai dari identitas, kegiatan usaha, sampai jumlah harta yang yang berkaitan dengan perpajakan tidak menggunakan berbagai sarana yang telah disebutkan di atas, melainkan ada sarana administrasi khusus yang disebut sebagai Surat Pemberitahuan (SPT). Menurut Resmi (2014) Surat Pemberitahuan (SPT) adalah surat yang oleh wajib pajak digunakan untuk melaporkan perhitungan atau pembayaran pajak, objek pajak dan/atau bukan objek pajak, harta dan kewajiban sesuai dengan ketentuan peraturan perundang-undanganperpajakan.

Penggunaan sarana ini terkait dengan sistem pembayaran yang akan masuk ke kas negara sebagai penerimaan pajak, yakni dalam Anggaran Pendapatan dan Belanja Negara (APBN).

$$
\text { Pajak Penghasilan }
$$
merupakan salah satu jenis pajak yang sistem pemungutannya menggunakan Self Assessement System dan memiliki kontribusi terbesar dalam penerimaan negara dari sektor pajak.Pajak Penghasilan $(\mathrm{PPh})$ adalah pajak yang dikenakan 
terhadap subjek pajak atas penghasilan yang diterima atau diperolehnya dalam suatu tahun pajak. Peraturan perundangan yang mengatur Pajak Penghasilan di Indonesia adalah UU Nomor 7 Tahun 1983 yang telah disempurnakan dengan UU Nomor 7 Tahun 1991, UU Nomor 10 Tahun 1994, UU No 17 Tahun 2000, UU No 36 Tahun 2008, Peraturan Pemerintah, Keputusan Presiden, Keputusan Mentri Keuangan, Keputusan Direktur Jendral Pajak maupun Surat Edaran Direktur Jendral Pajak.

Selama tiga tahun terakhir, penerimaan Pajak Penghasilan $(\mathrm{PPh})$ di Bukittinggi masih belum mencapai target sesuai dengan yang diharapkan oleh pemerintah. Berikut tabel perbandingan target dan realisasi penerimaan Pajak Penghasilan (PPh) tahun 2014-2016 :

Tabel 1 Perbandingan Target dan Realisasi Penerimaan Pajak Penghasilan (PPh) 2014 s/d 2016 di KPP Pratama Bukittinggi

\begin{tabular}{cccc}
\hline \multirow{2}{*}{ Tahun } & \multicolumn{2}{c}{ Penerimaan Pajak Penghasilan (PPh) } & \\
\cline { 2 - 4 } & Target & Realisasi & Persen \\
\hline 2014 & RP.77.561.027.532 & RP.49.958.115.398 & 64,41 \\
\hline 2015 & Rp.120.534.727.003 & Rp.70.282.769.263 & 58,30 \\
\hline 2016 & Rp.187.318.565.471 & Rp.76.862.591.258 & 41,03 \\
\hline
\end{tabular}

Sumber: KPP Pratama Bukittinggi.

Berdasarkan data diatas, dapat dilihat target penerimaan pajak penghasilan di Bukittinggi cukup tinggi. Pada tahun 2014, target penerimaan $\mathrm{PPh}$ yaitu sebesar RP.77.561.027.532, realisasinya sebesar RP.49.958.115.398 atau $64,41 \%$, pada tahun 2015 , target penerimaan

$\mathrm{PPh}$ sebesar Rp.120.534.727.003, realisasinya sebesar RP.70.282.769.263 atau 58,30\%, dan pada tahun 2016, target penerimaan pajak penghasilan sebesar Rp.187.318.565.471, realisasinya sebesar Rp.76.862.591.258 atau $41,03 \%$. Realisasi penerimaan pajak penghasilan masih jauh dari target dan belum sesuai dengan yang diharapkan oleh pemerintah. Dari tiga tahun terakhir, tahun 2014 dan 2015 penerimaan pajak penghasilan melebihi $50 \%$, namun pada tahun 2016 merupakan penerimaan pajak penghasilan yang paling terendah, yaitu tidak mencapai setengah atau $50 \%$ dari target.

Fitriani (2013)menyatakan bahwa jumlahwajib pajak terdaftar mempunyai pengaruh signifikan positif terhadap penerimaan pajak penghasilan, dan Pratama, dkk (2016) juga menyatakan bahwa jumlah wajib pajak berpengaruh signifikan terhadap penerimaan pajak penghasilan,namun bertolak belakang dengan penelitian yang dilakukan oleh Sari (2015) yang menyatakan jumlah wajib pajak yang terdaftar tidak berpengaruh terhadap penerimaan pajak penghasilan orang pribadi.

Hariyanto, dkk (2014) menyatakan jumlah surat pemberitahuan masa yang diterima mempengaruhi jumlah penerimaan pajak penghasilan badan, dan Harris, dkk (2016) menyatakan jumlah 
SPT memiliki pengaruh signifikan terhadap penerimaan pajak penghasilan, namun berbeda dengan penelitian yang dilakukan Mayasari dan Ucu (2015) menyatakan Jumlah SPT terlapor secara parsial tidak memiliki pengaruh terhadap penerimaan pajak penghasilan Pasal 21.

Berdasarkan latar belakang diatas maka rumusan masalah penelitian ini adalah 1) apakah jumlah wajib pajak memiliki pengaruh terhadap penerimaan pajak penghasilan, dan 2) apakah jumlah surat pemberitahuan memiliki pengaruh terhadap penerimaan pajak penghasilan.

\section{Metodologi}

Populasi yang digunakan pada penelitian ini adalah Kantor Pelayanan Pajak Pratama Bukittinggi, dan sampel yang digunakan dalam penelitian ini adalah jumlah penerimaan pajak penghasilan, jumlah wajib pajak orang pribadi dan jumlah surat pemberitahuan orang pribadi pada KPP Pratama Bukittinggi.

Data yang digunakan dalam penelitian ini merupakan data sekunder. Data diperoleh dari KPP Pratama Bukittinggi Periode 2014-2016). Hipotesis dalam penelitian adalah:

$\mathrm{H}_{1}$ : Jumlah wajib pajak berpengaruh terhadap penerimaan pajak penghasilan.
$\mathrm{H}_{2}$ : Jumlah surat pemberitahuan berpengaruh terhadap penerimaan pajak penghasilan.

\subsection{Definisi Operasional dan}

\section{Pengukuran Variabel}

Menurut Resmi (2014) pajak penghasilan $(\mathrm{PPh})$ adalah pajak yang dikenakan terhadap subjek pajak atas penghasilan yang diterima atau diperolehnya dalam suatu tahun pajak.Pengukuran variabel jumlah penerimaan pajak penghasilan dapat dilihat dari jumlah penerimaan pajak penghasilan, dan didapatkan dari laporan penerimaan pajak pada bagian PDI di setiap KPP. Berdasarkan Pasal 1 UU No.28 Tahun 2007 dalam Resmi (2014) wajib pajak adalah orang pribadi atau badan, meliputi pembayar pajak, pemotong pajak, dan pemungut pajak, yang mempunyai hak dan kewajiban perpajakan sesuai dengan ketentuan peraturan perundang-undangan perpajakan. Pengukuran variabel jumlah wajib pajak dapat dilihat dari jumlah wajib pajak orang pribadi, dan didapatkan dari laporan penerimaan pajak pada bagian PDI di setiap KPP.

Berdasarkan Pasal 1 UU No. 28 Tahun 2007, surat pemberitahuan adalah surat yang oleh wajib pajak digunakan untuk melaporkan perhitungan atau pembayaran pajak, objek pajak atau bukan objek pajak, harta dan kewajiban sesuai dengan ketentuan peraturan perundang- 
undangan perpajakan (Resmi, 2014).

Pengukuran variabel surat pemberitahuan dapat dilihat dari jumlah lembar surat pemberitahuan orang pribadi, dan didapatkan dari laporan penerimaan pajak pada bagian PDI di setiap KPP.

\section{Hasil dan Pembahasan}

Secara umum penelitian ini bertujuan untuk mendapatkan bukti secara empiris tentang pengaruh jumlah wajib pajak dan jumlah surat pemberitahuan terhadap penerimaan pajak penghasilan.

Menurut Ghozali (2013) statistik deskriptif memberikan gambaran atau deskripsi suatu data yang dilihat dari nilai rata-rata (mean), standar deviasi, varian, maksimum, minimum, dan lain-lain.

Tabel 2. Hasil Pengujian Statistik Deskriptif

\begin{tabular}{cccccc}
\hline & N & Min & Max & Mean & $\begin{array}{c}\text { Std. } \\
\text { Deviation }\end{array}$ \\
\hline $\mathrm{Y}$ & 36 & 21,83 & 23,21 & 22,3637 & 0,34145 \\
\hline $\mathrm{X} 1$ & 36 & 10,49 & 10,71 & 10,5962 & 0,07068 \\
\hline $\mathrm{X} 2$ & 36 & 2,20 & 7,40 & 4,2319 & 1,31068 \\
\hline
\end{tabular}

Uji asumsi klasik pada penelitian ini menggunakan uji normalitas, multikolonieritas, autokorelasi, dan heteroskedastisitas. Dari hasil pengolahan diperoleh hasil bahwa data sudah memenuhi uji asumsi klasik.Untuk pengujuan hipotesis dapat terlihat pada tabel 3 berikut ini :

Tabel 3. Hasil Pengujian Hipotesis

\begin{tabular}{lccc}
\hline \multicolumn{1}{c}{ Ket } & $\begin{array}{c}\text { Koef. } \\
\text { Regresi }\end{array}$ & Sig & $\begin{array}{c}\text { Penerimaan } \\
\text { Hipotesis }\end{array}$ \\
\hline (Constanta) & $-13,132$ & - & - \\
\hline X1 & 3,356 & 0,000 & H1 Diterima \\
\hline X2 & $-0,015$ & 0,638 & H2 Ditolak \\
\hline R-Square & \multicolumn{2}{c}{0,489} & \\
\hline F sig & \multicolumn{2}{c}{0,000} & \\
\hline
\end{tabular}

\subsection{Hasil Pengujian Hipotesis}

Dari tabel 4.2 secara umum persamaan regresi berganda yang dapat dibuat berdasarkan koefisien regresi seperti terlihat dibawah ini:

$$
Y=-13,132+3,365 X 1-0,015 X 2
$$

Dari tabel hasil uji Koefisien Determinasi $\left(\mathrm{R}^{2}\right)$ diatas dapat dilihat bahwa nilai $\mathrm{R}^{2}$ sebesar 0,489. Hal ini menunjukkan bahwa $48,9 \%$ jumlah penerimaan pajak penghasilan dipengaruhi oleh variabel jumlah wajib pajak dan jumlah surat pemberitahuan, sedangkan, 51,9\% penerimaan pajak penghasilan dipengaruhi oleh variabel-variabel lain yang tidak digunakan sebagai variabel independen dalam penelitian ini.

Dari tabel hasil uji statistik $\mathrm{F}$, diperoleh nilai sig $\mathrm{F}$ sebesar 0,000. Hasil uji statistik $\mathrm{F}$ dengan nilai 0,000 lebih kecil dari alpha sebesar 0,05 dengan ini dapat dijelaskan bahwa variabel jumlah wajib pajak dan jumlah surat pemberitahuan secara simultan berpengaruh terhadap penerimaan pajak penghasilan.

Variabel jumlah wajib pajak diketahui mempunyai koefisien regresi positif dan berpengaruh terhadap 
penerimaan pajak penghasilan, karena nilai koefisien regresi 3,356 dan signifikan 0,000 (lebih kecil dari 0,05). Hal ini mengindikasikan bahwa jumlah wajib pajak berpengaruh terhadap penerimaan pajak penghasilan. Maka kesimpulannya hipotesis pertama (H1) diterima. Pada hasil pengujian $\mathrm{H} 1$ bahwa jumlah wajib pajak berpengaruh terhadap penerimaan pajak penghasilan pada KPP Pratama Bukittinggi selama periode 2014-2016. Hal ini berarti semakin meningkat jumlah wajib pajak, maka akan semakin meningkat jumlah penerimaan pajak penghasilan.

Hasil penelitian ini sejalan dengan hasil penelitian yang dilakukan oleh Lainutu (2013) menyatakan jumlah wajib pajak PPh 21 orang pribadi yang terdaftar berpengaruh signifikan terhadap penerimaan pajak PPh Pasal $21 \mathrm{KPP}$ Pratama Manado, namun penelitian ini tidak sejalan dengan penelitian yang dilakukan Mayasari dan Ucu (2015) menyatakan bahwa jumlah wajib pajak terdaftar secara parsial tidak memiliki pengaruh terhadap penerimaan pajak penghasilan Pasal 21.

Variabel jumlah surat pemberitahuan yang diketahui mempunyai koefisien regresi negatif dan tidak berpengaruh terhadap penerimaan pajak penghasilan karena koefisien regresinya 0,015 dan signifikan 0,638 (lebih besar dari 0,05). Hal ini mengindikasikan bahwa jumlah surat pemberitahuan tidak berpengaruh terhadap penerimaan pajak penghasilan. Maka kesimpulannya hipotesis kedua (H2) ditolak. Pada hasil pengujian H2 bahwa jumlah surat pemberitahuan tidak berpengaruh terhadap penerimaan pajak penghasilan pada KPP Pratama Bukittinggi periode 2014-2016. Hal ini dikarenakan tidak semua wajib pajak melaporkan SPT setelah membayar pajak setiap bulannya, banyak dari mereka terlambat dan bahkan tidak melaporkan SPT mereka kepada petugas pajak. Oleh sebab itu jumlah surat pemberitahuan tidak berpengaruh terhadap penerimaan pajak.

Hasil penelitian ini sejalan dengan penelitian yang dilakukan Mayasari dan Ucu (2015) yang menyatakan bahwa jumlah SPT terlapor secara parsial tidak memiliki pengaruh terhadap penerimaan pajak penghasilan Pasal 21. Sedangkan berdasarkan penelitian yang dilakukan Hariyanto, dkk (2014) jumlah surat pemberitahuan masa yang diterima mempengaruhi jumlah penerimaan pajak penghasilan badan, sejalan dengan penelitian yang dilakukan Harris, dkk (2016) menyatakan jumlah SPT memiliki pengaruh signifikan terhadap penerimaan pajak penghasilan.

\section{Kesimpulan dan Saran}


Dari hasil analisis data dapat disimpulkan bahwa jumlah wajib pajak berpengaruh terhadap penerimaan pajak penghasilan sedangkan jumlah surat pemberitahuan tidak berpengaruh terhadap penerimaan pajak penghasilan pada KPP Pratama Bukittinggi periode 2014-2016.

$$
\text { Penelitian ini memiliki }
$$

keterbatasan penggunaan dua variabel independen yaitu jumlah wajib pajak dan jumlah surat pemberitahuan, untuk peneliti dimasa yang akan datang, disarankan untuk menambah variabel lain dari penelitian ini. Penelitian ini hanya menggunakan periode penelitian selama tiga tahun, untuk peneliti dimasa yang akan datang disarankan untuk menambah periode penelitian sehingga dapat mengetahui dan menganalisis kondisi lain diluar tahun penelitian ini.

\section{Daftar Pustaka}

Fitriani. Nanik,. "Pengaruh Jumlah Wajib Pajak Terdaftar dan Penerbitan Surat Paksa Terhadap Penerimaan Pajak Penghasilan Pada KPP Pratama Bantul",Jurnal Akuntansi, 1.2 Desember (2013).

Friskianti.Yossi dan Bestari Dwi Handayani,"Pengaruh Self Assessment System, Keadilan, Teknologi Perpajakan, dan Ketidak percayaan Kepada Pihak Fiskus Terhadap Tindakan Tax Evasion". Jurnal Jurusan Akuntansi, Fakultas Ekonomi, Universitas Negeri Semarang, Indonesia. AAJ 3.4 (2014).

Hariyanto. Yudi, Suhadak dan Siti Ragil H. "Pengaruh Jumlah Wajib Pajak,
Jumlah Surat Setoran Pajak, dan Jumlah Surat Pemberitahuan Masa Terhadap Jumlah Penerimaan Pajak Penghasilan Badan (Studi pada Kantor Pelayanan Pajak Pratama Malang Utara Periode 2010-2013)". Jurnal Administrasi Bisnis (JAB)| Vol. 10 No. 1 Mei 2014.|

Harris. Topowijono dan Sri. Sulasmiyati, "Pengaruh Self Assessment System dan Pemeriksaan Pajak Terhadap Penerimaan Pajak Penghasilan (PPh) (Studi pada Kantor Pelayanan Pajak Madya Malang Periode 2012-2014)". Jurnal Perpajakan (JEJAK)| Vol. 8 No. 1 2016. perpajakan.Student journal.ub.ac.id.

Lainutu, Amina. 2013. Pengaruh Jumlah Wajib Pajak PPh 21 Terhadap Penerimaan PPh 21 pada KPP Pratama Manado.Jurnal EMBA, l.3 (2013).

Mardiasmo. Perpajakan. Yogyakarta: Andi.(2016).

Mayasari. Rosalina Pebrica dan Ucu Permata Sari, "Pengaruh Jumlah Wajib Pajak terdaftar dan jumlah SPT Terlapor Terhadap Penerimaan Pajak Penghasilan Pasal 21 Pada KPP Pratama Pelembang Ilir Barat". Jurnal ilmiah Ekonomi Global masa kini volume 6.1(2015).

Pratama. Nicola Putra, Dwiatmanto dan Rosalita, Rachma Agusti. "Pengaruh Inflasi, Pemeriksaan Pajak dan Jumlah Wajib Pajak Terhadap Penerimaan Pajak Penghasilan (Studi Pada Kantor Pelayanan Pajak Pratama Malang Utara Periode 2010 Sampai 2014)". Jurnal Perpajakan (JEJAK)|, 8.1 (2016)

Resmi, Siti. Perpajakan: Teori dan Kasus. Jakarta: Salemba Empat.2014.

Sari, Wielda Permata. "Pengaruh kesadaran wajib pajak, kegiatan sosialisai perpajakan, pemeriksaan pajak dan jumlah wajib pajak yang terdaftar terhadap penerimaan pajak penghasilan orang pribadi di KPP Pratama Pekanbaru Tampan."Faculty 
of Economics Riau University, Pekanbaru, Indonesia. Jom FEKON 2.2(2015).

Suandy, Erly.. Perencanaan Pajak. Jakarta : Salemba Empat.2011 